\title{
Friendship as Potential? The Recognition of Teenagers' Peer Relationships at School
}

\author{
Riikka Korkiamäki \\ University of Tampere, School of Social Sciences and Humanities, Tampere, Finland \\ Email: riikka.korkiamaki@uta.fi
}

How to cite this paper: Korkiamäki, R. (2016) Friendship as Potential? The Recognition of Teenagers' Peer Relationships at School. Open Journal of Social Sciences, 4, 34-43.

http://dx.doi.org/10.4236/jss.2016.49005

Received: July 18, 2016

Accepted: September 19, 2016

Published: September 22, 2016

\begin{abstract}
The starting point for this paper is that children and young people's friendships have, significantly, been neglected as a communal resource. While the importance to teenagers of their friends and peers is widely recognized, their friendships are more often seen as a cause of risk behaviour than a resource with which risk could be prevented. Hence, the purpose of this theoretical paper is to challenge this predominant view by looking at teenagers' spontaneous friendships as inclusionary potential. The paper deals with young teenagers' friendships from the viewpoint of student welfare and preventive social work at school. It raises the question of how and with what teenagers' wellbeing should be supported in their everyday living environments such as school. The paper introduces Finnish basic education as a site for the prevention of early youths' marginalization, and studies how young people's mutual relationships are commonly perceived at school. Drawing from the theories of recognition, it is then suggested that recognizing the meaning and practices of students' friendship at school could advance their self-confidence, self-esteem and self-respect and hence, support better student wellbeing.
\end{abstract}

\section{Keywords}

Friendship, Peer Relationships, Prevention, Recognition, School Social Work, Young People

\section{Introduction}

In recent years, a growing awareness has arisen regarding the problems included in current ways of dealing with young people's risk of marginalization and social exclusion. It is widely acknowledged that the dominant early intervention tactics are not working efficiently, causing a growing need for child protection and youth welfare services and thus increased public expenditure on social welfare and health [1]. Research- 
ers, civil servants and politicians agree that investing in large-scale communal prevention of marginalization would benefit both individual and communal wellbeing, as well as both municipal and state finances [2].

However, as the recent research [3] has implied, the institutional reality is rather opposite: the energy and resources of social workers, educators, and other professionals often seem to be exhausted in problem-based interventions with individuals and, hence, there are very limited resources to invest in promoting the wellbeing of young people in their daily living environments. In some countries, of which Finland is an example, this is inconsistent with the child welfare, youth work and student welfare legislation, which strongly stress promoting the well-being of all children and youth and preventing the emergence of disadvantageous factors [4]. This tension between prevention and responding to crises is also recognized internationally, and there is a demand for research that can provide advice on how prevention could be achieved as part of everyday institutional practices such as basic education [5].

Lately, a growing body of research has stressed the potential of existing communal resources acting as preventive factors against adversity and marginalization [6] [7]. As Gilligan [6] argues, positive experiences in immediate living environments may contribute to broader resilience against difficult circumstances and increase children and young people's engagement with society. This important communal feature is usually seen to constitute in the context of family, school or other intergenerational and institutional relations. However, children and youth themselves often define the lack of friendship as the most important cause of social exclusion and marginalization [8]. This raises questions about how and with what young people should be supported and the way in which peer relationships are potentially overlooked by social work, youth work and school staff [7].

In this review, I contemplate the timely need for prevention-based measures and the request that it produces for social work and other daily practices at school. The focus is on teenagers' friendships which are generally considered among the most significant factors with respect to young people's wellbeing at school. As Judy Dunn [9] notes: if we do not interest ourselves in teenagers' friendships, we are missing a huge part of what is important in their lives and focal to their wellbeing.

\section{School as a Site for Preventive Social Work}

The viewpoint of prevention directs attention towards the communities and environments where children and young people live their everyday lives. Among such spaces, school is one of the most central ones. Teenagers spend a substantial part of their waking hours at school; and the incidents and relationships at school also influence what happens outside the school hours. In developed countries, nearly every child within the age group attends school, making school the place where all the teenagers can be reached regardless of their socio-economic background. Furthermore, at school the institutional adults-like teachers and social workers-have an opportunity to meet young people in their natural living environment. This enables a preventive manner 
towards the issues of wellbeing and marginalization and enables the early recognition of potential problems. According to a study conducted in Finland, also young people themselves expressed that school could take stronger responsibility for students' overall wellbeing [10].

In Scandinavia, including Finland, the expectations of early support and prevention of marginalization at school are, for large part, laid on the school social work. In spite of this, the tradition of school social work in Finland has been following the therapeutic-clinical model with the focus on working with individuals and solving problems through case work practice [11]. As a consequence, most students are not familiar with social work at school and, in case of problems or worries, they conceive school social worker as an unnatural or inaccessible source of support [12]. Many of the students, who have used the services and met with a school social worker, seem to perceive the support useless or meaningless [12]. Indeed, young people would prefer prevention-based and more easily accessible student welfare services. For instance, conversational therapy should, in their opinion, be available even before the problems occur [13]. Accordingly, the preventive social work at school, such as informal group activities and theme days, is highly appreciated by teenagers [14].

Recently in Finland, like in other Western countries, there has been a burgeoning demand for the redirection of school social work and student welfare services. It has been brought forward that the possibilities which schools have in promoting all children and youth's wellbeing are not utilized to their full potential [15]. Researchers have suggested that funneling the resources of school social workers towards more communal and structural practices would advance the timely and effective social work in schools [16] [17].

In Finland, a recent endeavor to answer the demand for better practice has been passed through a new Student Welfare Act (1287/2013). In the Act, the individual and communal student's welfare is perceived separately. The traditional-clinical school social work is set as part of the individual student welfare services, and the preventive school social work positions itself as part of the communal student welfare. The purpose of communal student welfare services is precisely to promote the wellbeing of all students, not just the ones with observable problems or difficulties. Furthermore, the Finnish Child Welfare Act (417/2007) positions school social work as part of the preventive child protection, the objective of which is to prevent the emergence or progression of difficulties or unwanted development. The goal is to decrease the amount of clients in actual child protection services through providing sufficient and timely support for children and young people while they are at school.

\section{Peer Relationships and School Social Work}

Recent research has revealed that social relationships and the problems that concern social relationships are among the most common reasons why teenagers seek the services of school social work or are referred to a school social worker [18]. Particularly friendships and peer relationships at school constitute a critical matter which substan- 
tially contributes or reduces the subjective wellbeing of teenagers [13].

\subsection{Peer Relationships at School}

Studies on informal social relationships of school, such as peer relations, are not rare among psychological, sociological or educational youth research. These studies have indicated that peer relationships are among the most central dimensions of school as a social environment-if not the most central one. To culminate, it can be argued that teenagers do not go to school to learn but to spend time with their friends [19]. Friendships and peer relationships at school have been found to interconnect with school enthusiasm, motivation, learning results, and educational aspiration [20] [21]. In addition, the overall wellbeing of teenagers-also outside of school-is strongly affected by social relationships at school [22] [23].

The public discussion about peer relationships at school typically focus on the problems and downsides of peer relations, such as bullying, loneliness, ganging or undesired behavior which is legitimized by friendship practices [24]. Research, too, has raised the interconnection between peer communities and marginalizing practices like consumption of drugs or alcohol, smoking, skipping class, dropping out of school, and delinquent behavior [25]-[27]. In consequence, the regulated practices of basic education are rather concerned on controlling the students' mutual relationships than on strengthening them. For instance, a common practice rather often is to order friends to have seats on the opposite sides of a classroom, or to deny peer gatherings in places that are out of teachers' sight [19].

Much less regarded are the peer relationships of school as a source of student wellbeing or better learning. It is easily forgotten that friends constitute not only a risk but an important source of social support, trust, and solidarity [22] [24]. Peer relationships at school demonstrably work as a platform for practicing communicative skills, receiving feedback for one's behavior, and adopting societally desired values, norms and attitudes [20] [24]. Acording to Konu [28], acquiring the ability to work as a member of a group, getting along with friends at school, and not being involved in bullying form the central elements that influence teenagers' subjective experiences of wellbeing.

\subsection{Friendships as Potential}

As said before, young people care for each other in multifarious and meaningful ways. Several youth network studies have illustrated that friends can be important sources of support, for instance, in coping with stressful situations [22]-[24]. Having a satisfactory relationship with same-age peers may compensate the lack of support from parents and buffer the negative effects of an unfavorable neighborhood or peer network [22]. In addition, peer groups provide supportive control and develop trust, solidarity and collective identities [19] [29]. Friendships and peer affiliations are even regarded as a late-modern version of communality, occasionally replacing traditional communities of care, support and social control [30].

The importance of friends and peers to teenagers raises questions about how and 
with what the youth should be supported [7]. Is the potential that resides in their friendships overlooked in the preventive practices of student welfare and school social work? According to Michael Bourdillon [31], friendship as a resource, the positive emotions connected to friendship, and the sense of belonging and togetherness are among the most neglected dimensions of children and young people's wellbeing.

The studies on school social work have, so far, paid some attention to students' friendships. The supportive potential of youth peer groups is recognized, for instance, in the implementation of informal group practices, and more targeted self-help groups [17] [32]. Friendship has also been acknowledged as potential in the practices where opportunities are constructed for students with disabilities to build friendships with non-disabled students [33]. These and other practices prove that professionals at school widely understand the social and educational significance of youth peer relations. However, the groups and pairs imposed together at school rarely originate from young people's spontaneous friendships, i.e., voluntary and personally chosen affective relationships between individuals [34].

Capitalizing on peer support, groups and communities, local networks, and communal capacities can be seen as a good example of strength-based social work at school, even when the working pairs, support groups or school communities are designated by adults [35]. However, it is not the same as recognizing the youths' spontaneous peer ties with their risks and resources. Therefore, the self-initiated friendships of young people may be seen as an understudied, biasedly viewed and unutilized potentiality within the environments where young people live their everyday lives-such as in school. The problems and downsides of teenagers' friendships and peer relationships should not be understated, but it is equally important to be conscious of and do research on the positive potential of their friendships.

\section{Promoting Wellbeing through the Recognition of Friendships}

A recent assessment released by the Finnish Prime Minister's Office [36] studied the effectiveness of policy measures in reducing social exclusion and welfare differences among children and young people. The report stated that the most important work against young people's marginalization and social exclusion is done at schools and as part of basic education. It is unquestionable that a great variety of measures through which this can be done are well recognized by the qualified professionals at schools. However, during the current economic recession and the predominant neo-liberal climate there seems to be no room for actions that are out of the mandatory. When "effectiveness" and "economy" become the keywords of student welfare, and when the size of personnel is minimal, study groups are large, and there is a vast number of students seeking for help with their acute problems, all the effort seems to go to "putting out the fires" instead of supporting the wellbeing of students in a preventive manner [2]. Hence, rethinking about the students' prevailing resources, strengths and existing relationships is very much welcomed. 


\subsection{The Project}

This final chapter of the paper is based on a co-operative research project ${ }^{1}$ that was conducted at the University of Tampere, Finland with child and youth care and basic education professionals. The purpose of the project was to find ways of supporting wellbeing and preventing marginalization of children and young people as part of their everyday institutional environments. Social workers, youth workers, teachers and administrative officials from various local institutions participated in the project together with the researchers. Collaborative workshops were organized to gain awareness of the good practices that complied with the idea of communal and strength-based convention as part of the mundane school work. An analysis of the shared dialogues revealed that no extra-curriculum and extra-cost projects were necessary to promote wellbeing and prevent exclusion. Instead, the idea of "mutual recognition" was discovered as a way of supporting teenagers' wellbeing in daily practices of, for instance, a school community [37].

\subsection{Theories of Recognition and Teenagers' Wellbeing}

The common idea of the theories of recognition is that it is a vital human need to become recognized by other people (and societies) as an equal and respected subject [38] [39]. The theories involve a normative assumption that "if you recognize another person with regard to a certain feature (...) you do not only admit that she has this feature but you embrace a positive attitude towards her for having this feature. Such recognition implies that you bear obligations to treat her in a certain way, that is, you recognize a specific normative status of the other person" [40]. Psychologically and educationally this signifies that "in order to develop a practical identity, persons fundamentally depend on the feedback of other subjects" [40]. This ensues in what Axel Honneth, perhaps the most well-known theorists of recognition, calls a struggle for recognition. According to Honneth [38], the success of this constant effort to receive positive and adequate recognition from others is determining to persons' development of self-confidence, self-esteem and self-respect.

Honneth's idea is shared by Charles Taylor [39] who suggests that a person's comprehension of oneself is fundamentally shaped by whether or not she receives recognition from surrounding others. Taylor highlights that those who fail to experience positive recognition i.e., "those who are depicted by others or the societal norms and values in a one-sided or negative way (...) will find it much harder to embrace themselves and their projects as valuable" [40]. Nonrecognition or misrecognition of one's values, interests and communities can imprison a person "in false, distorted, and reduced mode of being" [39].

To young people, it is important to receive recognition for activities and relationships which they find meaningful. In this way they can feel respected as individuals and as members of their own communities of importance [35]. It was found as part of our

${ }^{1}$ Project "Early recognition in curbing the marginalization of children and young people", 2013-2015, funded by the Academy of Finland. 
collaborative research project that this, in practice, required a three-step process: Firstly, an open and non-judgemental familiarization indicates genuine caring and interest in a young person's life and views. Through familiarization, it also becomes explicit what and who are important to each teenager. Secondly, the positive recognition of these issues and communities of importance reflects esteem and respect and builds trust between the young person and an adult. This, thirdly, enables supporting the youth-by the principle of maintaining what is good in their lives, and also attacking the potential problems when needed [37].

\subsection{Recognition, Friendships, and School}

Many theorists of recognition agree that the insecurity of receiving recognition in formal sense has led to the growing importance of recognition within private sphere like family and friendships [40]. Taking into consideration that friendship is a relationship where young people rather naturally give and receive recognition, friendship in its own right should be recognized as a relationship that is significant and resourceful to teenagers.

Because friendships mean a lot to most school-aged young people, it should be reconsidered how their spontaneous friendships are recognized (or misrecognized) at school. An adequately recognized teenager may feel respected by school adults, for instance, for being a good friend to her classmates or having a central role in a virtual game community, or she may experience acceptance as a member of her ethnically defined peer group. Meanwhile, another young person can sense misrecognition by adults who see her primarily as an immigrant, one of the smokers, a problem gambler, or perhaps generally "at risk". It may thus be useful to ask, if the adults at school-whether teachers, social workers, youth workers, or a school nurse-are conscious or even interested in who are the students' friends at school or elsewhere. Do the classmates constitute "significant others" for a young person or is her primary peer community somewhere else? Or do the adults at school accept a teenager as a member of the peer group that she defines overriding, or is the goal of intervention to link her with "better friends"?

People may feel accepted and included in all kinds of situations, environments and communities, and these experiences can be actively promoted almost anywhere-by all means at school [37]. While there are and will always be young people in need of individual and needs based interventions, there is also a demand for casual and community based measures and for course of action that aims at supporting children and young people's wellbeing in general [5]. Indeed, the objective of communal student welfare services could be to create an atmosphere where mutual recognition is the guiding principle of all daily activities at school-both among students and intergenerationally. If the opportunities of recognition and the situations of misrecognition are not realized by adults at school, the prevailing possibilities of supporting youths' wellbeing through self-confidence, self-esteem and self-respect may turn into demanding and expensive measures of reconstructive social work. 


\section{Acknowledgements}

The writing of this paper was supported by the Academy of Finland under Grant SA285592. I also thank my coresearchers Pia Bäcklund, Jouni Häkli, Kirsi Pauliina Kallio and Elina Stenvall and all the professionals who participated in our project for sharing and developing the thought on recognition and young people's wellbeing.

\section{References}

[1] Parton, N. (2006) "Every Child Matters": The Shift to Prevention whilst Strengthening Protection in Children's Services in England. Children and Youth Services Review, 28, 976-992. http://dx.doi.org/10.1016/j.childyouth.2005.10.002

[2] Heckman, J. (2011) The Economics of Inequality: The Value of Early Childhood Education. American Educator, 35, 31-47.

[3] Gilbert, N., Parton, N. and Skivenes, M. (2011) Child Protection Systems: International Trends and Orientations. Oxford University Press, Oxford. http://dx.doi.org/10.1093/acprof:oso/9780199793358.001.0001

[4] Forsberg, H. and Kröger, T., Eds. (2010) Social Work and Child Welfare Politics Through Nordic Lenses. Policy Press, Bristol.

[5] Cheon, J.W. (2008) Convergence of a Strengths Perspective and Youth Development: Toward Youth Promotion. Advances in Social Work, 9, 176-190.

[6] Gilligan, R. (2007) Adversity, Resilience and the Educational Progress of Young People in Public Care. Emotional and Behavioural Difficulties, 12, 135-145. http://dx.doi.org/10.1080/13632750701315631

[7] Emond, R. (2014) Longing to Belong: Children in Residential Care and their Experiences of Peer Relationships at School and in the Children's Home. Child \& Family Social Work, 19, 194-202. http://dx.doi.org/10.1111/j.1365-2206.2012.00893.x

[8] Cotterell, J. (2007) Social Networks in Youth and Adolescence. 2nd Edition, Routledge, London.

[9] Dunn, J. (2004) Children's Friendships: The Beginnings of Intimacy. Blackwell Publishing, Malden.

[10] Ministry of Social Affairs and Health (2012) Toimiva lastensuojelu. Report No. 28, Ministry of Social Affairs and Health, Helsinki.

[11] Perttula, R. (2015) Syrjäytymispuhe hallinnan strategiana opiskelijahuollon sosiaalityössä. University of Jyväskylä, Jyväskylä.

[12] Lunabba, H. (2013) När vuxna möter pojkar i skolan-insyn, inflytande och sociala relationer. University of Helsinki, Helsinki.

[13] Janhunen, K.M. (2013) Kouluhyvinvointi nuorten tulkitsemana. Dissertations in Social Sciences and Business Studies 52, University of Eastern Finland, Kuopio.

[14] Aaltonen, S., Berg, P. and Ikäheimo, S. (2016) Relationship between Young People and Welfare Services. Nordic Center for Welfare and Social Issues, Stockholm.

[15] Ahtola, A. (2012) Proactive and Preventive Student Welfare Activities in Finnish PreSchool and Elementary School: Handling of Transition to Formal Schooling and a National Anti-Bullying Program as Examples. University of Turku, Turku.

[16] McManama O’Brien, K., Berzin, S., Kelly, M., Frey, A., Alvarez, M. and Shaffer, G. (2011) School Social Work with Students with Mental Health Problems: Examining Different Practice Approaches. Children and Schools 33, 97-105. http://dx.doi.org/10.1093/cs/33.2.97 
[17] Brace, M. (2011) Who's There to Help? Assessment of Social Supports Received by Homeless and Unaccompanied Youth in High School. Ph.D. Dissertation, University of Hartford, West Hartford.

[18] Pippuri, T. (2015) Koulun sosiaalityön asiakkuudet ja asiakasprosessit. Licentiate's Thesis, University of Tampere, Tampere.

[19] Korkiamäki, R. (2013) Kaveria ei jätetä! Sosiaalinen pääoma nuorten vertaissuhteissa. Finnish Youth Research Society, Helsinki.

[20] Robnett, R. and Leaper, C. (2013) Friendship Groups, Personal Motivation, and Gender in Relation to High School Students' STEM Career Interest. Journal of Research on Adolescence, 23, 652-664. http://dx.doi.org/10.1111/jora.12013

[21] Reeves, E. (2012) The Effects of Opportunity to Learn, Family Socioeconomic Status, and Friends on the Rural Math Achievement Gap in High School. American Behavioral Scientist, 56, 887-907. http://dx.doi.org/10.1177/0002764212442357

[22] Traylor, A., Williams, J., Kenney, J. and Hopson, L. (2016) Relationships between Adolescent Well-Being and Friend Support and Behavior. Children \& Schools, 38, 179. http://dx.doi.org/10.1093/cs/cdw021

[23] Rose, T., Shadaiman, C., de Tablan, D. and Sharpe, T. (2016) Exploring Wellbeing and Agency among Urban Youth through Photovoice. Children \& Youth Services Review, 67, 114-122. http://dx.doi.org/10.1016/j.childyouth.2016.04.022

[24] Weller, S. (2007) “Sticking with your Mates?” Children's Friendship Trajectories during the Transition from Primary to Secondary School. Children and Society, 21, 339-351.

[25] Kirke, D. (2006) Teenagers and Substance Use: Social Networks and Peer Influence. Palgrave Macmillan, London. http://dx.doi.org/10.1057/9780230627628

[26] DeLay, D., Laursen, B., Kiuru, N., Salmela-Aro, K. and Nurmi, J.E. (2013) Selecting and Retaining Friends on the Basis of Cigarette Smoking Similarity. Journal of Research on Adolescence, 23, 464-473. http://dx.doi.org/10.1111/jora.12017

[27] Arunachalam, D. and Nguyen, D. (2016) Family Connectedness, School Attachment, Peer Influence and Health-Compromising Behaviours among Young Vietnamese Males. Journal of Youth Studies, 19, 287-304. http://dx.doi.org/10.1080/13676261.2015.1067674

[28] Konu, A. (2002) Oppilaiden hyvinvointi koulussa. PhD Dissertation, Tampere University Press, Tampere.

[29] Korkiamäki, R. (2011) Support and Control among "Friends" and "Special Friends": Peer Groups' Social Resources as Emotional and Moral Performances amidst Teenagers. Children \& Society, 25, 104-114. http://dx.doi.org/10.1111/j.1099-0860.2009.00262.x

[30] Chambers, D. (2006) New Social Ties: Contemporary Connections in a Fragmented Society. Palgrave Macmillan, London.

[31] Bourdillon, M. (2014) Neglegted Dimensions of Child Wellbeing. Children's Geographies, 12, 497-503. http://dx.doi.org/10.1080/14733285.2014.953315

[32] Leyba, E. (2010) How School Social Workers Integrate Service Opportunities into Multiple Elements of Practice. Children \& Schools, 32, 27-49. http://dx.doi.org/10.1093/cs/32.1.27

[33] Antle, B. (1998) Seeking Strengths in Young People with Physical Disabilities: Learning from the Self-Perceptions of Children and Young Adults. University of Toronto, Toronto.

[34] Rawlins, W. (2009) The Compass of Friendship: Narratives, Identities, and Dialogues. Sage, Thousand Oaks.

[35] Galloway, R. and Reynolds, B. (2015) Positive Psychology in the Elementary Classroom: The Influence of Strengths-Based Approaches on Children's Self-Efficacy. Open Journal of 
Social Sciences, 3, 16-23. http://dx.doi.org/10.4236/jss.2015.39003

[36] Ristolainen, H., Varjonen, S. and Vuori, J. (2013) Mitä tiedämme politiikkatoimien vaikuttavuudesta lasten ja nuorten syrjäytymisen sekä hyvinvointierojen vähentämisessä? Prime Minister's Office, Helsinki.

[37] Häkli, J., Kallio, K.P. and Korkiamäki, R., Eds. (2015) Myönteinen tunnistaminen. Finnish Youth Research Society, Helsinki.

[38] Honneth, A. (1995) The Struggle for Recognition: The Moral Grammar of Social Conflicts. Polity Press, Cambridge.

[39] Taylor, C. (1992) Multiculturalism and the Politics of Recognition (Edited by Amy Gutmann). Princeton University Press, Princeton.

[40] Iser, M. (2013) Recognition. In: Zalta, E.N., Ed., The Stanford Encyclopedia of Philosophy, Fall 2013 Edition. http://plato.stanford.edu/archives/fall2013/entries/recognition/

Submit or recommend next manuscript to SCIRP and we will provide best service for you:

Accepting pre-submission inquiries through Email, Facebook, LinkedIn, Twitter, etc.

A wide selection of journals (inclusive of 9 subjects, more than 200 journals)

Providing 24-hour high-quality service

User-friendly online submission system

Fair and swift peer-review system

Efficient typesetting and proofreading procedure

Display of the result of downloads and visits, as well as the number of cited articles

Maximum dissemination of your research work

Submit your manuscript at: http://papersubmission.scirp.org/ 